\title{
Strengthening Local Democracy or Neo-Liberal Conversions? New Local Governmental Legislation in Turkey
}

\author{
AYTEN ALKAN
}

\begin{abstract}
Among numerous transformation processes of the globalized neo-liberal era, governmental restructuring and decentralisation of the State have been distinctive and prevalent features, particularly in the countries characterized by highly centralised traditions. This transformation has resulted in rather complex and contradictory reforms at the local level: On the one hand, local community members have begun to be seen as 'customers' instead of citizens. But on the other hand, local autonomy and subsidiarity have gained more importance than before. In parallel with the redefinition of local identities, differences, local potentials and decision-making processes, the emphasis on local citizenship and local democracy has become sharper. After coming into force, the new Turkish (local) governmental legislation (2004-2006) has cloven these paradoxical processes and relations. This paper aims to question how far these paradoxes are embedded in the new legislation, and whether, in these circumstances, 'governmental decentralisation' directly connotes 'the empowerment of local governments and local communities'.
\end{abstract}

KEYWORDS: - Turkish local governmental system • (local) governmental restructuring • local democracy • neo-liberalism • Turkey

CorResPondence AdDREss: Ayten Alkan, Ph. D., Assistant Professor, Istanbul University, Faculty of Political Science, 34116 Beyazit - Istanbul, Turkey, email: aytenalkan72@gmail.com. 


\section{A Brief Historical and Structural Account of Local Governments in Turkey until the 1980s}

In the Ottoman period, artisan organizations, waqfs (charitable associations), kadls (law officers), and the central government had performed certain local services, functions, and responsibilities. The 'municipal' competences of the $k a d l$ had been mainly in auditing, supervising artisans, and in controlling prices, while waqfs had been functioning in the areas of local welfare, social public entities and public enterprises, such as public houses, hammams, public refectories, mainly organized around mosques.

In the Western European sense, local administrations started to be established following the Tanzimat administrative reforms (1839) as part of the modernization process. However, 'the motivation of the Tanzimat bureaucrats in institutionalising local administrations was to secure order and justice in raising taxes, providing a better offer of services, strengthening public security and economic power rather than reinforcing local democracy' (Ortayl1, 1980: 8). Thus, the very institutionalization of the Turkish local governments was based on centralist concerns rather than on the acknowledgement of 'the principle of local self-government'.

Nevertheless, as relations with the West developed, municipal organisations in the modern sense were established, starting from harbour cities and trade centres. The first municipality (SSehremaneti means 'city custody') was established in Istanbul in 1855. The Mayor (SSehremini means 'city custodian') was appointed by the central government and so were the City Council members.

Prior to the establishment of the Istanbul Sehremaneti, a Commission (Intizam-ı Sehir means the commission on 'the order of the city') was formed in order to develop suggestions on the proposed municipal organisation. The majority of the members of this commission were foreign nationals. Following the suggestions of the Commission, $6^{n c l}$ Daire-i Belediye (the sixth Municipal Bureau) was established in Pera (today's Beyoğlu), Istanbul, in 1858. As a location, Pera was no coincidence because, together with the neighbouring Galata (today's Karaköy), it was the quarter predominantly articulated by the West and mainly inhabited by non-Muslim tradesmen and bankers. And it was given the name ' $6{ }^{\text {th' }}$ because in Paris at that time, the most prestigious municipality was in the $6^{\text {th }}$ arrondissement. The head of the Municipal Bureau and the City Council members were also appointed by the central government. The Council could employ foreign national consultants, and the official language was French ${ }^{1}$.

Pursuant to law, the municipal organisation became prevalent in whole Istanbul in 1869 , and the municipal structure of Istanbul turned out to be 'federal' with the Istanbul Şehreminliggi at the top and with 14 sub-municipal Bureaus such as the $6^{\text {th }}$ Bureau of Pera. In accordance with the Municipal Law, the number of sub- 
municipalities increased to 20 in 1877. Since 1868, there have also been attempts to establish municipalities in towns other than Istanbul. Pursuant to law, municipal councillors could be elected by 'the Citizen Councils composed of locally prominent citizens' from among male real estate owners who had paid a certain amount of taxes. However, the City Council chairman could also be appointed by the central government from among the Council members.

Provincial bureaus started to be established in the second half of the $19^{\text {th }}$ century too. Provinces (vilayet) took the place of counties (eyalet), which reflected the transition (and the ideas behind that transition) from provinces to departments in France. Provincial Local Governments (PLGs) were under the absolute tutelage of the centre and its representatives. Following the proclamation of the Second Constitutional Monarchy (1908), a temporary municipal law (1912), and a temporary law on provinces (1913) also maintained the centralist tradition based on an appointment system and on lack of autonomy.

The village as the basic social unit had no legal personality until 1924. The first local governmental act of the Republic (established in 1923; 80\% of the country's population lived in rural areas) was the Village Act that gave villages a legal personality. In 1930, the Municipalities Act laid down the town administration rules. The provisions of the 1913 temporary law on PLGs have not changed much until very recently. As a matter of fact, the structure established by the Acts 1913, 1924, 1930 has been in force with only small changes throughout the Republican history.Thus, the Turkish local government system has three levels:

- the village: the village mukhtar (head) and the village ihtiyar heyeti (the council of prominent villagers) are elected by the village inhabitants

- towns (cities): the Mayor and the Municipal Council

- and provinces (the head of the provincial local government is the governor who is simultaneously the central government representative at the provincial level).

As we have seen, mahalle (neighbourhood), the smallest administrative entity since the time of the Ottoman Empire, is neither a local government unit (although the mahalle mukhtar and the mahalle council members are elected by the mahalle inhabitants in local elections) nor an autonomous legal entity. The main position of the mukhtar is a kind of 'bridging' between the mahalle and the departments of the central government, and sometimes the municipality when it comes to the procedures for men to be called up for military service, population affairs, delivery of the central government aid, etc. The unit has no budget, and the mukhtar is paid off by the central government.

As for village local governments (VLGs), in fact, the 1924 Act, which defined administrative structure, and the services to be carried out in the village, was envisioned as a basis for the multi-level local government system. The preamble 
to the Act noted that "classification of our municipalities into four levels is considered necessary, and these four levels shall refer to a village, town, city and to a large city, and separate legislation shall be enacted for each of the four levels...' Besides, it is understood that the legislator anticipated a kind of a Village Municipality. However, along with the 1930 Municipalities Act, this multi-level system was forgotten', and the related arrangement subjected the establishment of a municipality to either the population criterion or the administrative attribute of the settlement. Accordingly, (i) exceeding the 2000 population limit, it was possible for settlements to become a municipality, and (ii) when it came to city or district centres, it was / is a must to establish a municipality. So, the settlements with a population under 2000 were defined as villages. And for various reasons such as putting the village mukhtar on a salary, inadequacy of the village revenue, and the desire of any unit to exceed the 2000 limit to become a municipality rendered the VLG weak. Most of the rural services were undertaken either by regional bureaus of the central government or by the PLGs.

But on the other hand, the PLGs have always been subject to debate about whether or not their peculiarities fulfil the requirements of local self-government. Firstly, the governor, who is the head of the PLG -and also of the PLG Council until 2005- as well as the representative of its legal personality, is simultaneously the agent of the central government. Secondly, the PLG does not correspond to a 'commune administration'. It is rather an 'area administration', comprising the city/town centres and villages. Moreover, where there is no regional local government level, the PLGs have no functions to fill this gap.

Thus, it would not be wrong to argue that the closest unit which meets the 'assumed quality requirements and performs the duties and functions' of local government is a municipality in the local government/public administration system in Turkey. In parallel with the rise in urban population, the number of municipalities has also grown (Table 1). In 2005, there were 3,250 municipalities, whereas in 1923 there were only 421. In 2005, 87\% of the population in Turkey lived in municipal settlements. Moreover, the share of the population living in the metropolitan municipal settlements is $40 \%$. It needs to be noted here that, despite this dramatic change, the 1930 Municipalities Act remained in force until 2005. 
Table 1: $\quad$ Changes in the number of municipalities in time

\begin{tabular}{l|c}
\hline Year & $\begin{array}{l}\text { Number of } \\
\text { municipalities }\end{array}$ \\
\hline Prior to the Republic & 389 \\
1923 & 421 \\
1935 & 505 \\
1945 & 583 \\
1950 & 628 \\
1955 & 809 \\
1960 & 995 \\
1965 & 1,062 \\
1970 & 1,303 \\
1975 & 1,654 \\
1980 & 1,727 \\
$1981 *$ & 1,587 \\
1985 & 1,703 \\
1988 & 1,925 \\
1992 & 2,270 \\
1993 & 2,553 \\
1994 & 2,715 \\
1997 & 2,801 \\
2000 & 3,225 \\
2005 & 3,250 \\
$2009 * *$ & 2,903 \\
\hline
\end{tabular}

* The reason for the decline will be explained below.

** The reason for the decline will be explained below.

Source: Ministry of Internal Affairs, Turkish Municipalities Association, and Higher Board of Elections

To sum up, the Turkish local government system has been developing as part of the modernisation and Westernization project since the nineteenth century when Ottoman reform programmes were introduced. Traditional structures such as mahalle and waqf have largely been put aside in this process. Along with the Republic, the exquisite disaffiliation from the 1921 Constitution well reflects the notions of 'national sovereignty', 'unity', 'fear from the region', and thus a rather strict centralism has livened up the 'nature' of local government in Turkey. It is administratively, politically and financially dependent on the central government. The 1921 Constitution (Teşkilât-ı Esasiye Kanunu), two years prior to the declaration of the Republic, stands out as an exceptional case among the constitutions and acts regulating local governments in particular, and the public administration / government system in general. This Constitution anticipated provinces and community districts to provide broad autonomy and thereby regulating the central/centralist government as an exception. However, the first Constitution of the Republic (1924) and the subsequent ones (1961, 1982) followed the principles, introduced by the 1876 Constitution (Kanun-u Esasî) of 
the first Constitutional Monarchy, with only small changes instead of the decentralist and libertarian perspective of the 1921 Act.

\section{$2 \quad$ Neo-Liberal and Anti-Democratic Crossroads in the 1980s}

In Turkey, '1980' is widely taken as a trend in a variety of fields, almost like B.C. \& A.D. Diverse political, economic, cultural, or governmental analyses are no exception. The socio-economic and political changes, brought about in the 1980s and strengthened in the 1990s, were not specific to Turkey. During these years, two major processes became perspicuous and hegemonic in the world economy and politics: (i) neo-liberalism and obliteration in the social welfare perspective, marked most dramatically by the regime transformation in the ex-socialist bloc following 1989, and (ii) the erosion of the central state, accompanied by measures to reinforce local autonomy and subsidiarity. Those two parallel transformations have been affecting both local communities and local governments in contradictory ways. On the one hand, local governments and communities had to largely assume the burden of the sustainability of public support to disadvantaged social groups. But on the other hand, certain changes as part of the process of administrative / governmental restructuring have been put on the agenda. Several of those changes aim at stronger democratisation, political participation and decentralisation, while others comprise deregulation, non-public-budget administrative units, privatisation, etc., which have specific negative effects on disadvantaged groups. In parallel to these changes, quite complicated and contrasting relations have been shaping at the local level. While local community members are being gradually conceived as 'customers' instead of citizens, contradictorily enough, the emphasis on local citizenship has become sharper in parallel with the redefinition of local identities, differences, local potentials and decision-making processes (Eraydın, 2001: 369-71). In the context of these dialectical transformations, local politics, citizenship, representation, participation, and provision of public services have become the focus of new arguments.

In Turkey, the early 1980s are also characterised by a military coup d'état. The military regime lasted for three years. It reshaped the country at almost any level and in almost any context. Towards 1980, in parallel to the economy, pervasive political and social depression and crisis conditions were preponderant in the country. This atmosphere 'ended' up with the $12^{\text {th }}$ September military coup. Shortly before the coup, the January 241980 Economic Stabilization Program was put into practice, following the two preceding packages of precautionary measures in 1978 and 1979 (Boratav, 1995: 114-38). Although the January 24 program duration was 3 years, the main characteristics introduced by the program were also maintained by civil governments following the military regime period. Thus, this period laid the foundations for the era in which opportunities were created for unproductive and unearned rental income where liberalisation and privatisation became programmatic choices of the government and where the character of the welfare state was gradually worn out. 
Consequently, the period after 1980 is characterised by the intense commodification of urban properties and services as much as urban land, and by the formation of a great unearned rental income sphere. It is noteworthy that the 1980s (starting from the very military regime period) were the years of an intense legislative activity concerning construction and redevelopment, housing, urban land, institutional local administrative structure, etc. One of the initial decisions of the military regime was to abolish certain metropolitan area municipalities (see Table 1) and to annihilate the legal personality of about 150 villages. (Keleş, 2009: 240-3) The former were incorporated into the nearby big cities. And the latter were incorporated into the nearby municipalities. The continuum of this process would be the establishment of the Greater Metropolitan System in 1984. Initially, there were 3 greater metropolitan municipalities (Ankara, Istanbul, Izmir). Today, their number has increased to 16. In 1981 and 1984, two subsequent housing development acts were adopted. They were accompanied by legal arrangements considering coastal zones, tourist investments, conservation competences, and gecekondu (slum) areas. In 1985, urban planning competencies were completely decentralised in municipalities.

In the era in which all these new legal and structural arrangements ran in parallel with a neo-liberal pro-private sector climate and within the traditional clientalist political culture, local politics/governments began to be considered as a distribution sphere of urban rents rather than as providers of local public services and socio-spatial justice. The process of 'commercializing of local politics' and professional composition of municipal councils (local councils dominated by local businessmen and merchants) can partly be understood in this framework. What is meant by 'tradesmen-isation' of municipal councils in the related literature of Turkey signifies this composition and its political and socio-ethical implications. One more point to put under this title shall be the pertinent article (Local Governments) of the 1982 Constitution to the extent it differs from that of the 1961 Constitution ${ }^{2}$.

(i) Article 127 rules that the 'decision-making bodies' (municipal council and committee, provincial council and committee) of local governments shall be formed by elections, whereas they used to be 'general decision-making bodies' (excluding local committees). The Constitutional Court abated one of the rules of the new Provincial Local Government Act (1987) allowing appointed central public officials to enter the provincial committee in terms of this clause. It needs to be pointed out that this arrangement was not the result of the will for democratisation in the era in which debates were made even on the appointment of executive bodies. Excluding executive bodies (Mayor, the head of the province, mukhtar) from the rule for being elected leaves the way open for an appointment system. And the head of the province is already the governor as mentioned before. 
(ii) In 1961, it was written that the 'populace' would elect these bodies, whereas in 1982, there was 'the electorate mentioned in the law', which in fact made no difference, but possibly was reflecting the legislator's fear of using the term 'populace'.

(iii) The rule that 'the establishment, functions, tasks, and competences of local governments can only be regulated by law', the same as in 1961, was better clarified by adding the following wording: 'and accordingly the principle of local self-government'.

(iv) Article 127 introduced 'particular governance forms for larger settlement centres' which gave way to the establishment of metropolitan municipalities as explained above.

(v) The most significant difference between 1961 and 1982 lies in the rules concerning administrative tutelage of the central government at the local level. In contrast to the 1961 Constitution, administrative tutelage is overtly mentioned in Article 127, and the legitimate objectives of this tutelage are rather vague. They are set

- to ensure the provision of local services in accordance with the principle of the integrity in public administration,

- to secure the unity of the civil service,

- to safeguard public interest, and

- to meet local needs.

The last distinction is an exception to the rule. The wording is the following: 'judgment concerning the objections to the elected local bodies'; 'the supervision of their loss of competence requires adjudication', i.e., 'local elected bodies or their members that are subject to an investigation or prosecution for the delicts related to their administrative functions can be put out of office by the Minister of Interior as a temporary precaution until the definitive judgment', which has been used for political reasons from time to time. These regulations with regard to the constitutional and legal frame on the one hand and as a basis of neo-liberal socioeconomic restructuring on the other, which I have tried to sum up here, are important to see the background of the upcoming new legislation in the mid2000s. Additionally, the new legislation that came into force and was backed up by arguments like 'democratisation, reinforcement of local governments and local democracy' did not touch these anti-democratic arrangements at all, just like the reservations shown by the Republic of Turkey in the European Charter of Local Self-Government (ECLSG). 
As it is known, Turkey has been an EU candidate country since 1999, and it has also been one of the founder members of the European Council (EC) since 1949. The attitude of the then Government towards the ECLSG, prepared and declared by the EC and finalized at the conference of the European Ministers for Local Government in 1985, can be handled as a reflection of the Turkish State's political will concerning the reinforcement of local democracy and autonomy. The Turkish Government signed the Charter in 1988 and acknowledged it by the Cabinet decision in 1992. However, this acknowledgement involved certain reservations. What is noteworthy is that although one of the reference points was this Charter during the recent debates on new legislation, Turkey has never annulled the reservations to the following ECLSG articles:

- Article 4/6: Local authorities shall be consulted, insofar as possible, in due time and in an appropriate way in the planning and decision-making processes for all the matters which concern them directly.

- Article 6/1: Without prejudice to more general statutory provisions, local authorities shall be able to determine their own internal administrative structures in order to adapt them to local needs and ensure effective management.

- Article 7/3: Any functions and activities, which are deemed incompatible with the holding of a local elective office, shall be determined by statute or fundamental legal principles.

- Article 8/3: Administrative supervision of local authorities shall be exercised in such a way as to ensure that the intervention of the controlling authority is kept in proportion to the importance of the interests which it is intended to protect.

- Article 9/4: The financial systems on which the resources available to local authorities are based shall be of a sufficiently diversified and buoyant nature to enable them to keep pace as far as practically possible with the real evolution of the cost of carrying out their tasks. (Although one of the clauses of Article 127 of the Turkish Constitution reads as 'local governments are warranted income proportionally to their functions').

- Article 9/6 \& 7: Local authorities shall be consulted, in an appropriate manner, on the way in which redistributed resources are to be allocated to them. - As far as possible, grants to local authorities shall not be earmarked for financing specific projects. The provision of grants shall not remove the basic freedom of local authorities to exercise policy discretion within their own jurisdiction.

- Article 10/2 \& 3: The entitlement of local authorities to belong to an association for the protection and promotion of their common interests and to belong to an international association of local authorities shall be recognised in each State. - Local authorities shall be entitled, under such 
conditions as may be provided for by the law, to co-operate with their counterparts in other States. (Under Article 127 of the Turkish Constitution, a Cabinet decision is required for this).

- Article 11: Local authorities shall have the right of recourse to a judicial remedy in order to secure free exercise of their powers and respect for such principles of local self-government as are enshrined in the constitution or domestic legislation.

In a report prepared and published by the Prime Minister's Office (T.C. Başbakanlık, 2003), during the debate on the reconstruction of public administration, it was underlined that local governments were under 'strict central supervision', and that they had 'not enough financial resources', and that there was a need for local government restructuring in accordance with the ECLSG. Although the new legislation, favoured by this report and others, had been adopted, Turkey did not withdraw the reservations mentioned above.

\section{A Long-Standing Need for Strengthening Local Governments and Communities vs. an Urgent 'Need' for Escaping 'Public Responsibility'}

Since the early 1960s, the necessity to re-arrange the sphere of local government and administration in Turkey was discussed at various levels ${ }^{3}$. With the US Marshall Program, Turkey has been undergoing rapid urbanization especially since the 1950s. The role of urban areas has gained ground in economic, social and political life. The transition to a multi-party system ${ }^{4}$ following the Second World War added weight to the concerns of urban settlements and local governments because they became an issue of competition between political parties. Gecekondu (slum) settlements began to be conceived as 'vote depots'. The acts that regulate local administrations have become rather obsolete. Excessive centralism, dependence on the central government with regard to competences and financial resources, and heavy supervision and control over local bodies should be modified to meet reasonable standards. In addition, the relations with the EEC and the EU necessitated the efforts to approximate the Turkish local democracy standards to the Western European countries. And finally, in the era of globalisation and liberalisation, transformations in the role of the State, and Turkey's relations with and dependence on international financial institutions put the issue under compulsion. The World Bank and the IMF have been in a position to interfere in the stipulations of financing local services and investment, and even in the pricing schedule of public services in detail (Keleş, 2009: 501-5).

Under these circumstances, the question of whether local governments or firms and corporations would take the dwindling place of the State was on the agenda of the $\mathrm{AKP}^{5}$ government, which came to power in 2002 - and which is still in power. The need for the reform concerning local governments was included in the government programme. Shortly after its coming into being, the government 
started restructuring public administration. The process was proceeding at a rate of knots. After drawing up the Main Draft Law on Public Administration, which was a fundamental regulation for others, Draft Laws on Municipalities, Metropolitan Municipalities, and Provincial Local Governments were published in January 2004. These drafts became laws in 2004-2005. It is clear that the main concern was 'the urban' because the Village Act dating back to 1924 was 'forgotten'. Two other Draft Laws on Financial Resources of Provincial Local Governments and Municipalities could not yet have a chance to become laws. All these acts (except the one on the metropolitan municipalities) were sent back to the Parliament by the President. It was notable that the predominant concern of the President was related to 'nationalist' and 'unitary' worries rather than to the socio-economic paradigm of the legislation. In the justification text supporting the decision to send the acts back to the Parliament, it was said:

...the very existence of the need for restructuring public administration is an undeniable verity. It has become a necessity to make re-arrangements in order to enable public administrative bodies to provide a rapid and efficient service... However, it is vital to take care of these re-regulations not to harm the unity of the country and the nation, the unitary state structure, the balance between central and local governments, to secure congeniality in the public interest, and to secure public services and constitutional principles.

The Parliament re-enacted the legislation with only small changes (except for the Main Act). Thus, there is still some ambiguity in the domain, because although the main local government legislation has been adopted and has come into force, there is a lack of the basic principles set out in the Main Act. In other words, delegation has been largely made to local governments, especially to the PLGs, but the competence of the central government bodies has not yet been re-described. The new Municipalities (Article 14) and PLGs (Article 6) Acts laid down the subsidiarity principle, at least on paper, by indicating that the 'services shall be offered in the localities nearest to the citizens and by using optimum methods'; however, as mentioned above, the new financial resources arrangements for these local governments have not yet been made; another ambiguity lies in the question 'by which means?' This may create serious problems because, again according to these two acts, the criteria for priority-setting in services are the 'service urgency' and the 'financial situation of that local administration.' (The same principle is also potentially risky for the disadvantaged groups of the local community and/or for those whose voice cannot be heard easily because these particularities are decisive in determining 'what is an urgent priority'.)

Many of the competences which were at central governmental bodies' responsibility before have been decentralized to Municipalities and PLGs, and many have become shared responsibility by these new legal arrangements. But neither disparities between regions, which are very sharp in Turkey, nor 
organisational, technical, staff, equipment inadequacies of local governments, especially in small settlements, and a shortage of adequate financial resources have been taken into consideration. The delegation of so many new responsibilities in a milieu where many local governments cannot fulfil their actual tasks properly will result in new service and investment deficits. Without any doubt, this gap will be filled by other agents, i.e., by the private sector; local governments will raise more and more internal and foreign loans; and the privatisation process will gain speed. In fact, all of these have been continuing processes since late 1980s; but this new phase seems to be an institutionalising and mainstreaming one without leaving almost any space for withstanding. Considering that local governments are authorised by a broad and almost limitless privatisation competence, and by their broadened range of borrowing options, this assumption may imply not a 'possibility of deviation', but a 'policy'.

Although the Main Draft Act on Public Administration did not come into force, many new proposed arrangements were realised on a piece-meal basis by other legal arrangements. In addition, new regulations have been introduced by considering the government personnel, social security, and financial audit systems. These involve the introduction of 'norm staff', contract-based positions, temporary and flexible working forms, and 'voluntary work' regarding the sphere of (local) government affairs and public service. The latter, as formulated under the title of 'volunteer participation in municipal/provincial local government services' (MA, Article 77; PLGA, Article 65), allows the local governments to use the programmes for the 'volunteer' participation in services ... for the elder, women, children, and the disabled; in order to reinforce solidarity and participation in town/province, and to procure efficiency, productivity, and financial savings for services.' In addition to tagging 'public services, citizen voluntarism and financial savings' together, the mentioned target groups are also problematic. The arrangement puts the already disadvantaged social groups in a more fragile and probably dependent position, connecting their wellness to voluntarism. Especially within a socio-political culture where disadvantaged social groups are seen as 'indigents' rather than 'subjects/citizens', arrangements as such have the potential to increase the asymmetric relationship not only between the local government and the citizen, but also between citizens. One more clause illustrating this perspective is the content of the article titled 'the right to local citizenship' that reads as follows:

Everyone is the citizen of the town where he/she lives. Citizens have the right to participate in municipal decision-making and in service delivery, to be informed about municipal activities and to benefit from municipal aid. It is required that the aid is offered in accordance with human dignity. (MA, art.13)

The arrangement legitimates the relationship that is predisposed to create political dependence, as experienced very intensively during local elections. When 
bringing 'rights' and 'aid' together, it decomposes the very meaning of citizenship. And, last but not least, these arrangements have the potential to reproduce and even reinforce gender asymmetries in local communities in various ways: Firstly, the ones who apply for municipal aid are women rather than men, although in the household name (Alkan, 2005: 194-95). So, the approach to the concept of citizenship from the perspective of 'helping' makes female local citizenship more fragile. And secondly, the local female 'charitable and public service' organisations play a safety valve role in the collapsing welfare state. Many female organisations do not speak of their own needs, but of the needs of others. Thus, these arrangements have the potential to promote female organisations as such, especially in the context where provision of services, in addition to voluntarism, is linked culturally to traditional female roles and is socially considered as more appropriate for women.

One should not ignore the fact that in the Turkish local governments, the new legal regulations define and adopt certain modes and forms of civic participation and consultation, such as the City Council that is formed by the representatives of professional chambers, trade unions, universities, non-governmental organisations, etc., or drawing up the 'strategic plan' after consulting the universities, professional chambers, and related non-governmental organisations. However, the limited experience shows that the City Councils, especially in the metropolitan areas, are gathered and established upon request of Mayor, and usually the representatives of the private sector organisations (e.g., chamber of industry or trade) get strong positions in the councils. Thus, in practice, the measures aiming at more democratic ways of governance lay out all the defects of a pure 'pluralistic' approach on the one hand and of clientelism on the other, and, above all, they seem like 'make-up' rather than opening the way to the bottom-up styles.

\section{Conclusion}

Localisation and decentralisation may well bring together democratisation, empowerment of local communities, and strengthening local democracy. However, they may not. In other words, localisation and decentralisation are the conditions, but not the guarantee of democracy improvement, welfare society, and strong local communities. Especially in the conditions where socio-economic problems, such as unequal income distribution, class-, gender-, and ethnic-based deprivations, geographical and economic development disparities, and where political problems such as clientalist culture in local government processes are not commensurately taken into consideration. But on the contrary, this kind of speedy decentralisation may even result in a setback considering all these values and standards. Thus, if we get back to the question of 'strengthening local democracy or neo-liberal conversions?', the conclusion of this paper will basically be in favour of the latter. There is no doubt that new legal arrangements introducing the so-called reform concerning local governments in particular and public administration system in general are realized in the era of neo-liberal restructuring. 
The motivation behind this is a reinforcing market/private sector orientation, demeaning the public services sector rather than improving local democracy by introducing self-government systems and empowering local communities.

This argument can be reinforced by certain epitomes either from the letter and spirit of the law or from practice. Finally, I will give three examples:

(i) As said before, although mukhtar and ihtiyar heyeti are elected by neighbourhood inhabitants during the local elections in Turkey, they are neither local government units, nor have they a strong position within the administrative structure. The experience of countries like Sweden, Norway, Italy, Brazil, Germany, Britain, and the USA indicates that strong administrative organisations at the neighbourhood level not only make urban administration more efficient, but they also mobilise 'silent citizen groups'. Also in Turkey, in order to foster local participation and to render administrative structure more efficient, strengthening mukhtarlık through equipping this institution with certain local government competencies has been a very frequent proposition for a long time. However, the new Municipalities Act has contented itself with a rather flexible clause (Article 9) which introduces no structural change in the position of mukhtar and mahalle, except for a slightly broader recognition. However sincere the attempt might be to empower local communities, the democratisation of the local government system should have taken a different approach to this deeply rooted unit.

(ii) Table 1 shows that the number of municipalities was reduced from 3,250 to 2,903 in the period from 2005 to 2009 . The number would have been higher (by more than 1,000), but the related 'special' act had been taken to the Supreme Court, and only around 350 of them lost their municipal status, and some of them were transformed into village local governments, while others were incorporated into certain sub-municipalities of the Metropolitan Municipalities. What is common to them all is that none of the communities have been consulted.

(iii) It is generally known that there has been a 'Kurdish problem' in Turkey since the early years of the Republic. It is a long and complicated 'story' that will go beyond the limits and main issues of this paper. However, it is important to bring out that the 1990s are the years when the Kurdish movement 'legalised' and established political parties. The preceding DTP party ('pro-kurdish' Democratic Society Party) ${ }^{6}$ had 20 MPs (they could be elected independently) in the Parliament. Since the 2007 general elections, it has also been in power in many municipalities of Eastern and South-eastern Turkey (now passed to the newly established Party) where there is a dense Kurdish population. There is a 10 per cent countrywide barrage of political parties, and thus the 'Kurdish' party cannot be represented in the Parliament, although in certain localities it can get up to 70 per cent of the vote (that is why in the last general election, the candidates entered the election 
"independently" and thus managed to break the barrage). It means that, inter alia, local power meets a 'genuine local representation' need for the Kurdish population. This differs from other regions and local communities. However, the administrative, political, and supervisory pressure on local governments in control of the formerly DTP has been rather fierce and disproportional. A recent example was the abolishment of a municipal council that had taken the decision of 'multi-lingual service'. After that, the Mayor was removed from office.

These are only a few examples that highlight the degree and limits of understanding of 'local democracy' in Turkey. The same examples discredit the arguments of 'empowering the local community' by new 'reform' regulations.

This transformation process may also result in unintended, yet partial consequences. It is not possible to presume without any margin of error which socio-economic groups will be the resurgent, and which ones the losers. Since the pertinent sphere implies not only institutions, rules, laws, and global hegemonic processes, but also non-institutional politics, social movements, deliberations, groups' and people's agency, and local differentiations, there might be different responses to global and national effects, there might as well be leakages and counter-processes, thus unforeseen developments as well.

\section{Acknowledgements}

This article is the revised version of a paper presented at IPSA's $21^{\text {st }}$ World Congress of Political Science, 'Global Discontent? Dilemmas of Change' (12-16 July 2009, Santiago, Chile). The study was financially supported by the Scientific Research Projects Support Program (BAP) of the University of Istanbul. UDP-3637/22042009.

\section{Notes}

${ }^{1}$ For a further and detailed account of this period see Rosenthal, 1980.

${ }^{2}$ It needs to be mentioned that both of these constitutions, i..e., the last two Constitutions of the Republic of Turkey were drawn up during the military regime periods. Turkey is still governed by that Constitution (1982), although almost one third of it has been changed since then.

${ }^{3}$ It would not be wrong to take the 1961 Constitution as a springboard for contemplations on re-regulating the local government system and many other areas because the Constitution launched the 'planned development' by linking development efforts to the central/national development plans. Between 1961 and 1980, many reports were prepared, certain projects were developed to aim at restructuring public administration in general, and local government system in this context. Moreover, in 1978, the Ministry of Local Government was established with a view to 'get over administrative and financial obstructions that local governments face, a new reality in our fast changing society, by applying the necessary regulations to make these bodies more efficient and functional'. However, the Ministry survived only for 22 months before being abolished. In addition, a period of 'new social municipal governance' was experienced in certain localities that were 
in control of the left-wing Republican People's Party (CHP) in the mid 1970s to 1980. Thus, in fact, there was a fairly rich pool of ideas, projects, and experience to be used to improve local governments and communities. The question arises why they could not succeed. The answer lies in resolving the multi-layered problems that could be the topic of another paper. However, to put it in a nutshell: (i) absence of the continuum between different governments, and between central and local government in terms of 'maintaining good experience', (ii) deeply rooted centralism, and thus 'fear' from the local and 'independent will', (iii) and undoubtedly, every so often, military interventions can be counted as notable factors.

${ }_{5}^{4}$ 1923-1946 was a single-party period (M. Kemal Atatürk’s CHP).

5 Adalet ve Kalkınma Partisi (Justice and Development Party). One of the main characteristics of the party is conservatism (in terms of Islam and traditionalism). The Supreme Court prosecuted the party in 2008 (which is not a rare case in the Turkish political history) due to activities, speeches and clandestine objectives that were in contradiction with the laicism principle of the Constitution (the same reasons have been taken into consideration by the Supreme Court to ban the Prosperity Party (Refah Partisi RP) and the Islamic Virtue Party (Fazilet Partisi - FP) recently. These were the AKP's predecessors. Actually, apart from the discussions and tensions on whether AKP is an Islamic party or not, there is no doubt that it is a true liberal one in the economic sense.

${ }^{6}$ The Democratic Society Party (Demokratik Toplum Partisi - DTP) was shut down in December 2009 by the Supreme Court, and the Peace and Democracy Party (Barış ve Demokrasi Partisi - BDP) was established instead. The predecessors of the DTP were: 1990-1993 the People's Labour Party (Halkın Emek Partisi HEP), 1993-1994 the Democracy Party (Demokrasi Partisi - DEP), 1992-1994 the Freedom and Democracy Party (Özgürlük ve Demokrasi Partisi - ÖZDEP), 1994-2003 People's Democracy Party (Halkın Demokrasi Partisi HADEP), 1997-2005 the Democratic People's Party (Demokratik Halk Partisi - DEHAP). Except for the DEHAP, all the predecessors of the DTP were shut down by the Supreme Court. DEHAP denounced itself and merged with the DTP.

\section{References}

Alkan, A. (2005) Yerel Yönetimler ve Cinsiyet: Kadınların Kentte Görünmez Varlı̆̆l [Local Governments and Gender: Women's Invisible Existence in the City] (Ankara: Dipnot).

Boratav, K. (1995) Türkiye İktisat Tarihi [Economic History of Turkey] (1908-1985), $5^{\text {th }}$ ed., (İstanbul: Gerçek Yayınevi).

Eraydın, A. (2001) Küreselleşme-Yerelleşme ve İşlevleri Farklılaşan Kentler [Globalisation -Localisation and Changing Functions of Cities], Cevat Geray'a Armăgan (Ankara: Mülkiyeliler Birliği).

Keleş, R. (2009) Yerinden Yönetim ve Siyaset [Local Self-Government and Politics], $6^{\text {th }}$ ed., (İstanbul: Cem).

Ortayl1, İ. (1980) Türkiye İdari Tarihi [Administrative History of Turkey] (Ankara: TODAİE).

Rosenthal, S. (1980) Foreigners and Municipal Reform in Istanbul: 1855-1865, International Journal of Middle East Studies, 11(2), pp. 227-245, DOI: 10.1017/S0020743800054404.

Başbakanlık, T. C. (2003) Değişimin Yönetimi için Yönetimde Değişim [Change in Administration for the Management of Change] (Ankara: Başbakanlık). 